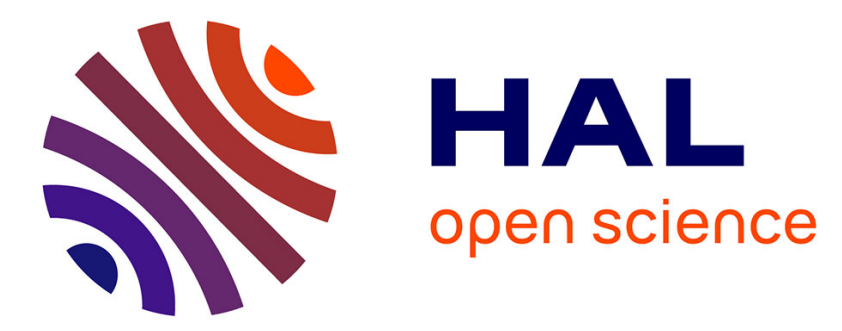

\title{
Quantifying the effect of matric suction on the compressive properties of two agricultural soil using an osmotic oedometer
}

Kai Cui, Pauline Défossez, Yu-Jun Cui, Guy Richard

\section{- To cite this version:}

Kai Cui, Pauline Défossez, Yu-Jun Cui, Guy Richard. Quantifying the effect of matric suction on the compressive properties of two agricultural soil using an osmotic oedometer. Geoderma, 2010, 156 (3-4), pp.337-345. 10.1016/j.geoderma.2010.03.003 . hal-00539602

\section{HAL Id: hal-00539602 https://hal.science/hal-00539602}

Submitted on 24 Nov 2010

HAL is a multi-disciplinary open access archive for the deposit and dissemination of scientific research documents, whether they are published or not. The documents may come from teaching and research institutions in France or abroad, or from public or private research centers.
L'archive ouverte pluridisciplinaire HAL, est destinée au dépôt et à la diffusion de documents scientifiques de niveau recherche, publiés ou non, émanant des établissements d'enseignement et de recherche français ou étrangers, des laboratoires publics ou privés. 


\title{
Quantifying the effect of matric suction on the compressive properties of two agricultural soil using an osmotic oedometer K. CUI ${ }^{\text {ab }}$, P. DÉFOSSEZ ${ }^{\text {ac* }}$, Y.J. CUI ${ }^{\mathrm{d}}$, G. RICHARD ${ }^{\mathrm{e}}$
}

\author{
${ }^{a}$ INRA, Unité Agro-Impact, UR1158, rue F. Christ, 02007 Laon, France. \\ ${ }^{b}$ Present address: Southwest Jiaotong University, School of Civil Engineering, 610031 \\ Chengdu, Sichuan, P.R.China \\ ${ }^{c}$ Present address: INRA, UMR614 FARE, 2 Esplanade Roland Garros, BP 224, 51686 Reims \\ cedex 2, France. \\ ${ }^{d}$ Ecole Nationale des Ponts et Chaussées, UR Navier, 6 et 8, avenue Blaise Pascal, Cité \\ Descartes, Champs-sur-Marne, 77455 Marne La Vallée cedex 2, France. \\ ${ }^{e} I N R A$, UR0272 Science du Sol Orléans, 2163 Avenue de la pomme de pin, BP 20619 Ardon, \\ 45166 Olivet CEDEX, France. \\ *Corresponding author: \\ Tel:+33 3232399 49, Fax:+33 3237936 15, E-mail: Pauline.Defossez@ reims.inra.fr
}

\begin{abstract}
The compaction of cultivated soils by agricultural machines considerably affects both the structure and physical properties of soil, thus having a major impact on crop production and the environment. The soil mechanical strength to compaction is highly variable both in time and space because it depends on soil type (texture), soil structure (porosity) and soil moisture (suction). This paper is devoted to the effect of soil suction on the compression index $C_{\mathrm{c}}$ which is one of the mechanical parameters that describes the soil mechanical strength to compaction. We used an oedometer compression tests with suction control implemented by using the osmotic technique to study the compression index of a loamy soil and a sandy soil. Soil samples were prepared by compacting soil powder passed through $2 \mathrm{~mm}$ sieve, to a dry bulk density of 1.1 or $1.45 \mathrm{Mg} \mathrm{m}^{-3}$. The mechanical stress and the suction ranges considered corresponded to field conditions, with vertical stress less than $800 \mathrm{kPa}$ and suction less than $200 \mathrm{kPa}$. The results show that the compression index $C_{\mathrm{c}}$ changed little with suctions ranging from 10 to $200 \mathrm{kPa}$ for the two soils at different initial densities. By contrast, the variation of $C_{\mathrm{c}}$ is significant when soil suction is close to zero for the loamy soil at an initial dry bulk density of $1.1 \mathrm{Mg} \mathrm{m}^{-3}$. From a practical point of view, this variation in compression index with suction is a useful result for modelling soil strain due to traffic and predicting the compaction of cultivated soils.
\end{abstract}

Keywords: Soil compaction, compressibility, suction

\section{Introduction}

Soil compaction due to the passage of agricultural machines is a major factor in the evolution of soil structure in heavily mechanized agricultural systems. It therefore has considerable consequences on crop production and the environment. The intensity of soil deformation caused by machines depends on the soil's mechanical properties which are themselves dependent on moisture related to the climatic conditions and agricultural operations. From a mechanical viewpoint, it is essential to know how mechanical parameters vary as a function of soil moisture, in order to predict soil compaction.

Soil compaction mainly depends on two mechanical parameters, i.e. precompression stress $\left(p_{\mathrm{c}}\right)$ and the compression index $\left(C_{\mathrm{c}}\right)$. Precompression stress indicates the maximum stress to which the soil has been subjected. The compression index corresponds to the slope of the Virgin Compression Line (VCL). These parameters are estimated from oedometer tests giving the soil compression curve $\left(e-\log \sigma_{\mathrm{v}}\right)$ linking the void ratio, $e$, and the applied vertical stress, $\sigma_{\mathrm{v}}$. Note that in soil mechanics, the two parameters $p_{\mathrm{c}}$ and $C_{\mathrm{c}}$ are specific parameters for 
saturated soils. Their use has been extended to soils in unsaturated state (Fredlung and Rahardjo, 1993). The effects of soil state on these two parameters have been the subject of different works. Precompression stress increases with soil bulk density (Alexandrou and Earl, 1998; Canarache et al., 2000; Imhoff et al., 2004; Lebert and Horn, 1991; McBride, 1989; Rücknagel et al., 2007) while the compression index decreases with soil bulk density (McBride, 1989; Salire et al., 1994; Imhoff et al., 2004). Precompression stress decreases with soil water content (Alexandrou and Earl, 1998; Défossez et al., 2003; Imhoff et al., 2004; Mosaddeghi et al., 2006). For the compression index, some authors have found that it decreases with water content (Zhang et al., 1997; Défossez et al., 2003) while others have observed that water content has an insignificant effect (Larson et al., 1980; O'Sullivan, 1992; Smith et al., 1997; Arvidsson and Keller, 2004; Imhoff et al., 2004; Mosaddeghi et al., 2006). Thus it seems that the studies performed up to now have provided contradictory effects for water content. The experimental conditions were quite varied. Regarding structural state, both remoulded and intact soil samples have been tested. What is more, there are also large differences for moisture state. For instance, Gupta and Larson (1982) studied soils at different soil suctions ranging from 2 to $1100 \mathrm{kPa}$, whereas Imhoff et al. (2004) examined two suctions of 10 and $100 \mathrm{kPa}$. Moreover, the results were obtained under different drainage conditions (from the bottom, the top or both bottom and top) and for different loading times (from 2 min to $3 \mathrm{~h}$ ). For clayey soils, these loading times were probably not long enough to reach equilibrium state, even under the most favourable drainage conditions from both bottom and top (Bardet, 1997).

Physically, when compressing a soil sample at constant water content, the hydrous state of the soil sample changes as the degree of saturation increases. As a result, the compression index, and to a certain extent the precompression stress, change too. The only way to keep soil hydrous state constant is by maintaining the soil suction constant, which is what has been done in the field of geotechnics (Alonso et al., 1990; Cui and Delage, 1996; Rampino et al., 2000; Mancuso et al., 2002; among others). Two techniques have been used to control soil suction during mechanical stress application: the axis translation and the osmotic techniques. Most of the results obtained in geotechnics show that compression index decreases with increasing suction and were obtained for soils with very high dry bulk densities (1.67$1.98 \mathrm{Mg} \mathrm{m}^{-3}$ ) (Table 1). In the present work, oedometer tests with controlled suction were conducted on cultivated soils. The osmotic technique (Delage and Cui, 2000) was applied for suction control. The aim of this work is to study the effect of soil water suction for two soils (a loamy soil and a sandy soil) at two initial bulk densities $\left(1.1\right.$ and $1.45 \mathrm{Mg} \mathrm{m}^{-3}$ ) on the compressibility behaviour of cultivated soils.

\section{Material and method}

\subsection{Tested soils}

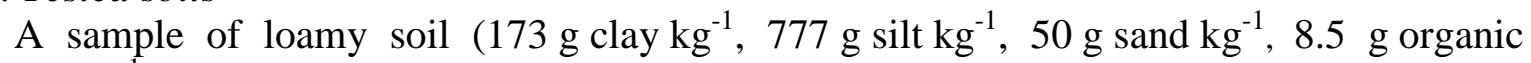
carbon $\mathrm{kg}^{-1}$ ) was taken from an experimental station of the National Institute of Agronomic Research (INRA), located at Mons, France. In addition, a sample of sandy soil (190 g clay kg1, $230 \mathrm{~g} \mathrm{silt} \mathrm{kg}^{-1}, 580 \mathrm{~g}$ sand $\mathrm{kg}^{-1}, 22 \mathrm{~g}$ organic carbon kg${ }^{-1}$ ) was taken from another INRA experimental station at Breuil, France. The soils were air-dried in the laboratory, ground and passed through a $2 \mathrm{~mm}$ sieve.

\subsection{Osmotic Oedometer with a system of soil imposition}

The osmotic technique for suction control is based on the use of a cellulose semipermeable membrane and an aqueous solution of organic polyethylene glycol [PEG] molecules. When the soil is separated from the PEG solution by the membrane, water can cross the membrane whereas the PEG molecules in solution cannot due to their large size. The 
water stops flowing once equilibrium state is reached; there is thus the same suction in the PEG solution and the soil. This suction is known from the PEG calibration curve. According to Delage et al. (1998), Delage and Cui (2000), there is a unique relation between PEG concentration $C$ (g PEG/g water) and suction $s(\mathrm{MPa})$, independent of the molecular weight of the PEG. For suctions lower than $6.25 \mathrm{MPa}$, the relation is linear and defined by: $s=11 C^{2}$

A standard oedometer was adapted to the osmotic technique, allowing compression tests at controlled suction. Fig. 1 shows the osmotic oedometer. The cell base was grooved to homogenize the distribution of the PEG solution; a fine sieve was placed over the grooves to protect the semi-permeable membrane placed between the sieve and the soil sample. A closed circuit activated by a peristaltic pump was designed to circulate the PEG solution. A 1 litre bottle was used to ensure a quasi-concentration in spite of water exchanges with the soil sample. A capillary tube placed on the sealed bottle permitted monitoring water exchanges between the PEG solution and the soil sample. The bottle was placed in a thermostatic water bath at $20 \pm 0.5^{\circ} \mathrm{C}$ to avoid any temperature effects on the water exchange measurements. In addition, the entire system was installed in an air-conditioned room $\left(20 \pm 1^{\circ} \mathrm{C}\right)$. In order to quantify the change of water volume due to temperature and evaporation, a second bottle full of PEG solution with a capillary tube was placed in the water bath.

\subsection{Test procedure}

Four series of tests were carried out. The first series involved six tests on the loamy soil.

For each sample preparation, $103.62 \pm 0.05 \mathrm{~g}$ dry powder was used. The soil powder was humidified by pulverization to reach $0.125 \mathrm{~g} \mathrm{~g}^{-1}$ water content; the sample was prepared by compaction in the oedometer cell to reach dimensions of $70 \mathrm{~mm}$ in diameter and $24 \mathrm{~mm}$ high, with a dry bulk density of $1.1 \mathrm{Mg} \mathrm{m}^{-3}$. The initial suction of the compacted sample before compression test was about $200 \mathrm{kPa}$, based on a retention curve shown in Fig. 2. This retention curve was measured on soil with a dry bulk density of $1.1 \mathrm{Mg} \mathrm{m}^{-3}$ using a tensiometer inserted in samples having various water contents.

One compression tests using osmotic technique took between 2 days to three weeks depending on soil suction and soil hydraulic conductivity. This limits the number of compression tests so that most of authors limited the number of replicates to one and examined a maximum of 4 suctions (Table 1). We performed tests on remoulded samples sieved < $2 \mathrm{~mm}$ with special care of sample building: all samples were performed by precompaction of a soil powder at the same water content of $0.125 \mathrm{~g} \mathrm{~g}^{-1}$. This procedure was supposed to limit the variability of our measurements and was chosen to balance the lack of repetitions for the different series.

The six compression tests were performed at different suctions: 0, 10, 50, 100, 180 and $200 \mathrm{kPa}$, each test having been started with a first suction application process under zero vertical stress. The suction was applied either by circulating PEG solution of the desired concentration or pure water (for zero suction). Equilibrium was indicated by stabilizing the solution level in the capillary tube. Equilibrium state reached when there was no change in variation of water volume in the capillary tube or in the soil. An example of variation in water volume to reach a controlled suction of $50 \mathrm{kPa}$ was shown in Fig. 3a for a sample initially prepared at a suction of $200 \mathrm{kPa}$ according to the water retention curve (Fig. 2). The positive value indicated the water was absorbed by the soil. At the end of 200 hours, equilibrium state was reached without change in water volume. It was observed that equilibrium time depended on the amplitude of suction changes: three days for $200 \mathrm{kPa}$ and 18 days for zero suction for the loamy soil at a dry bulk density of $1.1 \mathrm{Mg} \mathrm{m}^{-3}$. Note that a soil wetting process was observed for $200 \mathrm{kPa}$ suction, indicating an initial suction slightly higher than $200 \mathrm{kPa}$. 
The compression was performed under constant suction condition by step-loading using a pneumatic system: 10-20-50-100-200-400-800 kPa. Loading time was function of time needed to reach equilibrium. The displacement stabilization was controlled by the two sensors (accurate to $0.01 \mathrm{~mm}$ ) installed symmetrically on both sides of the oedometer cell. Loading time took approximately $40 \mathrm{~min}$. Fig. $3 \mathrm{~b}$ shows the variation of water volume for the same sample of $50 \mathrm{kPa}$ before being placed under step-loading vertical stress. The negative value indicated the water was driven out of the soil to the capillary tube. Unloading was carried out following the same stress steps until $50 \mathrm{kPa}$. The final water content was determined by ovendrying at $105^{\circ} \mathrm{C}$ during 24 hours.

The second series involved five tests also on the loamy soil. Unlike the previous tests these five tests were performed on samples compacted at different water contents $0.125,0.126$, $0.135,0.14,0.20 \mathrm{~g} \mathrm{~g}^{-1}$, chosen as a function of the water retention curve (Fig. 2) to obtain different corresponding suctions: $20,80,100,150,200 \mathrm{kPa}$. The samples also had an initial dry bulk density of $1.1 \mathrm{Mg} \mathrm{m}^{-3}$ and they were loaded in the same way as the first series. This procedure of sample preparation was quicker that the procedure used in the first series. We performed this second series as a repetition. The first series was performed for samples obtained after pre-compaction of soil at the same water content and then subjected to wetting to reach the different controlled suctions while the remoulded sample structure of the second series were obtained by pre-compaction of soils at different initial water content.

The third series involved four tests on the loamy soil at different suctions $(0,20,80$, $200 \mathrm{kPa}$ ). The protocol used in the first series was applied except that the samples were compacted at a denser state with a dry bulk density of $1.45 \mathrm{Mg} \mathrm{m}^{-3}$.

The fourth series involved three tests on the sandy soil at different suctions $(0,80$, $200 \mathrm{kPa}$ ). As in the third series, the protocol used in the first series was applied with all the samples compacted at the same water content $\left(0.125 \mathrm{~g} \mathrm{~g}^{-1}\right)$ and the same dry bulk density $\left(1.45 \mathrm{Mg} \mathrm{m}^{-3}\right)$.

\subsection{Calculation procedure}

Fig. 4 presents a typical compression curve showing the mechanical parameters: the compression index $C_{\mathrm{c}}$ i.e. the slope of the virgin compression line (VCL), the parameter $C_{\mathrm{s}}$ and the precompression pressure $p_{\mathrm{c}}$. The curves generally have a sigmoidal shape (i.e. Sshape). The method used for $C_{\mathrm{c}}$ determination was similar to that presented by Baumgartl and Köck (2004) and Gregory et al. (2006) for compression curves with a sigmoidal shape. For each loading step, the ratio $\Delta e / \Delta \log \sigma_{\mathrm{v}}$ between the change in $e$ and the change in decimal logarithmic of $\sigma_{\mathrm{v}}$ was calculated and drawn as function of the mean value of $\sigma_{\mathrm{v}}$. The compression index $C_{\mathrm{c}}$ was taken equal to the mean value of the two maximum values of $\Delta e / \Delta \log \sigma_{\mathrm{v}}$. We also calculated the average of the ratios $\Delta e / \Delta \log \sigma_{\mathrm{v}}$ for stresses higher than $p_{\mathrm{c}}$ (i.e. all stresses after the maximum curvature of the compression curve) and compared this value to the $C_{\mathrm{c}}$ estimation to examine the effect of procedure on $C_{\mathrm{c}}$ calculation. The parameter $C_{\mathrm{s}}$ was the slope of unloading phase. The precompression pressure $p_{\mathrm{c}}$ was the intercept of the VCL and a line with slope $C_{\mathrm{c}}$ drawn with the first point of the curve (Bardet, 1997).

\section{Results}

\subsection{Compression curves and determination of compression index}

The variation of void ratio versus the logarithm of vertical stress $\left(e-\log \sigma_{v}\right)$ is shown in Fig. 5 for the loamy soil samples in the first tests series. The curves generally have a sigmoidal shape, and can be separated into two groups according to suction values. For suctions from 0 to $100 \mathrm{kPa}$, the void ratio is clearly smaller than that at suctions higher. In addition, it can be observed that there is a fall for zero suction under a vertical stress comprised between 10 and $20 \mathrm{kPa}$. All the curves show that a slight reduction in void ratio 
until precompression stress was followed by a more significant reduction of void ratio. The slope of the unloading phase $\left(C_{\mathrm{s}}\right)$ is almost the same for all the curves, i.e. equal to 0.023 \pm 0.007 . As far as the precompression stress is concerned, Fig. 5 shows that it increases with increasing soil suction.

Fig. 6 shows the change in the values of $\Delta e / \Delta \log \sigma_{\mathrm{v}}$ calculated for the first test series by using every two successive vertical stresses as a function of vertical stress. A maximum value can be observed for a vertical stress of around $100 \mathrm{kPa}$, except in the case of zero suction where the maximum value was obtained for a vertical stress of $20 \mathrm{kPa}$. This demonstrates that the compression curves departed from the elasto-plastic model generally used to model the soil response to compression where the void ratio $e$ varies linearly with $\log \sigma_{\mathrm{v}}$ (i.e. the logarithmic model) (Fredlung and Rahardjo, 1993; Bardet, 1997).

Fig. 7 shows the maximum values of $\Delta e / \Delta \log \sigma_{\mathrm{v}}$ which is an estimation of the compression index $C_{\mathrm{c}}$ in comparison to the average value of $\Delta e / \Delta \log \sigma_{\mathrm{v}}$. It appears that the compression index $C_{\mathrm{c}}$ and the average value of $\Delta e / \Delta \log \sigma_{\mathrm{v}}$ are nearly constant from 10 to $200 \mathrm{kPa}$. The mean value of the compression index is 0.67 ; the mean value of the average $\Delta e / \Delta \log \sigma_{\mathrm{v}}$ is 0.58 . On the contrary, when the soil sample was near to water saturation, a significant change in compression index could be observed; the compression index based on the maximum $\Delta e / \Delta \log \sigma_{\mathrm{v}}$ increased while the average value of $\Delta e / \Delta \log \sigma_{\mathrm{v}}$ decreased.

The variations of void ratio versus the logarithm of vertical stress $\left(e-\log \sigma_{v}\right)$ are shown in Fig. 8 for the loamy soil samples at $1.45 \mathrm{Mg} \mathrm{m}^{-3}$ in the third tests series and in Fig. 9 for the sandy soil at $1.45 \mathrm{Mg} \mathrm{m}^{-3}$ in the fourth tests series. Both series displayed compression curves in agreement with a logarithmic model described by two parameters: the parameter $\left(C_{\mathrm{s}}\right)$ and the compression index $\left(C_{\mathrm{c}}\right)$.

The parameter $\left(C_{\mathrm{s}}\right)$ is $0.021 \pm 0.001$ for all tests on the loamy soil and $0.035 \pm 0.001$ for those on the sandy soil. This agrees with the majority of the results available in the literature that the slope $C_{\mathrm{s}}$ is independent of suction (Alonso et al., 1990).

\subsection{Variation of compression index with texture and structure}

Fig. 10 shows the variation of compressibility as a function of soil suction for soil samples prepared (i) with the same initial water content of $0.125 \mathrm{~g} \mathrm{~g}^{-1}$ (thus with the same microstructure) and then equilibrated at different initial water suctions (first test series), and (ii) with various water contents as shown in Fig. 2 (second test series). It can be observed that there is one repetition for each suction value. The results show that the compression index is almost constant (0.69) in the suction range between 10 and $200 \mathrm{kPa}$, whatever the initial microstructure.

Fig. 11 shows the effect of soil type and soil dry bulk density on the variation of compression index with controlled suction. For the loamy soil, the compression index with the dry bulk density of $1.45 \mathrm{Mg} \mathrm{m}^{-3}$ is lower than that with the dry bulk density $1.1 \mathrm{Mg} \mathrm{m}^{-3}$. Moreover, the compression index in the case of $1.45 \mathrm{Mg} \mathrm{m}^{-3}$ dry bulk density increases in the low suction range, as opposed to the trend in the case of a dry bulk density of $1.1 \mathrm{Mg} \mathrm{m}^{-3}$. For the sandy soil, the compression index is lower than for the loamy soil and remains nearly constant $(0.35)$ whatever the soil suction.

\section{Discussion}

\subsection{Compression curves and determination of compression index}

The sigmoidal S-shape compression curve was also observed by various authors in the fields of geotechnical engineering (Graham and Li, 1985; Janbu, 1985; Leroueil, 1996; Perret et al., 1995; Smith et al., 1992) and agriculture (Baumgartl and Köck, 2004; Keller et al., 2004; Gregory et al., 2006). Keller et al. (2004) showed the effect of loading time on the variation of a compression curve. Better drainage conditions and longer loading time led to a 
compression index value. Gregory et al. (2006) proposed to attribute the sigmoidal S-shape to the rapid loading rate adopted in studies of soil compression in agriculture. In this study, the compression curves were determined with a unique loading time of $40 \mathrm{~min}$. Although this duration was much shorter than that practiced in geotechnical engineering, which demands a period of 24 hours, it was found to be long enough to stabilize vertical displacement. Drainage conditions were also the same in all tests. Therefore the sigmoidal S-shape cannot be due to a drainage effect in our experiments. Baumgartl and Köck (2004) considered that the sigmoidal $\mathrm{S}$-shape is explained by soil maximum packing density: the minimum void ratio that a soil can reach was estimated as $e=0.27$. This falls out of the range of the void ratio where sigmodal effects on the compression curve appeared in our study. For instance, the inflexion of the compression curve was be observed for void ratio $e=0.9$ for $s=100 \mathrm{kPa}$ in Fig. 5. We propose to explain this feature by giving an interpretation of the processes in play during the compression processes and consider that compression involves both aggregate rearrangement and aggregate deformation. Indeed, when compressing a soil sample, aggregate re-arrangement occurs first, defining an initial deformation regime; when the vertical stress becomes high enough and when there are insufficient macro-voids for further aggregate rearrangement, soil compression mainly occurs through aggregate deformation, with a second deformation regime. One can suppose that both deformation processes involve with two distinct compression ratio, this can give rise to an $\mathrm{S}$-shaped compression curve. At low suctions, the aggregate stiffness is lower (Cui and Delage, 1996); aggregate deformation occurs earlier or at lower vertical stresses so that both deformation regimes may occur together. By continuing this line of thought, at very high stresses, all the curves would join together when all the voids disappear. From our observation on loess, we can notice that the final magnitude of $\Delta e / \Delta \log \sigma_{\mathrm{v}}$ for both bulk densities of 1.1 and $1.45 \mathrm{Mg} \mathrm{m}^{-3}$ is similar for high stresses (Fig.s 6 and 8). This corroborated the assumption that compression occurs through process of aggregate deformation at high stress whatever the initial bulk density.

At saturation, we also observed an effect of soil structure on the compression curve: a fall in void ratio was observed on the compression curve under vertical stress at around $10-20 \mathrm{kPa}$ (Fig. 5). This decrease would correspond to a collapse of soil microstructure. It appears that our soil sample satisfies the conditions for the microstructure collapse phenomenon: it had a fairly loose structure, signifying that a significant volume of macro-voids existed between aggregates. As mentioned above, these aggregates must have been significantly weakened by the initial water saturation process; they deformed and re-arranged at the same time, even under low vertical stresses. This led to a significant volume change and collapse. After this process, aggregate re-arrangement no longer occurred, whereas only aggregate deformation continued, providing a smaller compressibility (Jennings and Burland, 1962; Barden et al., 1973).

Due to the S-shaped compression curve, the procedure for the compression index estimation is important and may change the variation of compression index with soil suction (Fig. 7). Different procedures are used in literature to estimate the compression index, most of them consider the slope of the VCL according to standard of soil mechanics (Bardet, 1997) and some of them consider the slope near the maximum curvature (Baumgartl and Köck, 2004; Gregory et al., 2006). The standard method can not be applied rigorously when the compression curve present an S-shape and did not vary linearly with $\log \sigma_{\mathrm{v}}$ for all stress range. This could induce a discrepancy in the compression index measurements and explain partially the contradictory effects of water content observed between different works. Some authors have found that the compression index decreases with water content (Zhang et al., 1997; Défossez et al., 2003) whereas numerous authors have not observed any significant effect of water content (Larson et al., 1980; O'Sullivan, 1992; Smith et al., 1997; Arvidsson and Keller, 2004; Imhoff et al., 2004; Mosaddeghi et al., 2006). The hydrous state of soils is not 
controlled in standard mechanical tests: the suction and the water content may change during deformation as function of experimental conditions for drainage and loading time which vary in the different studies. This could also explain the disparity in observations reported in literature.

As far as the variation of the precompression stress is concerned, the results obtained in the present work confirm the observation made on both agricultural soils and geotechnical soils: precompression stress increases when soil suction increases (Cui and Delage, 1996; Alexandrou and Earl, 1998; Défossez et al., 2003; Imhoff et al., 2004; Mosaddeghi et al., 2006).

\subsection{Variation of compression index with soil texture}

Our result highlighted an effect of soil texture on the magnitude of the compression index: it was low for the sandy soil. This agrees with numerous studies on soil compressibility, as reported by Bardet (1997). We also found that the higher the dry bulk density, the smaller the compression index. Similar findings were reported by McBride (1989), Salire et al. (1994) and Imhoff et al. (2004).

The effect of soil texture on the variation of the compression index with suction was not clearly established in the literature (Table 1). Two features can be distinguished: one group of soils exhibiting compression index that decreases with suction. This feature was reported for all soil textures: for clay soils (Romero et al., 2003), for loess soils (Cui, 1993; Chen et al., 1999), and for sandy soils (Rampino et al., 2000; Mancuso et al., 2002). The compression index of a second group of soils increased with suction. This was reported for loess soil (Adams and Wulfsohn, 1998; Kogho et al., 2001; Wang et al., 2002; Futai and Amleida, 2005) and for sandy soils (Futai and Amleida, 2005). Our results tend to agree with the second group. Nevertheless the loess soil with a dry bulk density $1.1 \mathrm{Mg} \mathrm{m}^{-3}$ at saturation shows variations of $C_{\mathrm{c}}$ with soil suction, a characteristic belonging to both groups depending on the method used for its estimation. This suggests that soil porosity may change the variation of the compression index with soil suction. Further experiments are required this assumption, especially for low bulk density for which few observations were reported in literature (Table 1). Our study was focussed on remoulded samples to avoid the variability of intact samples but this approach should be applied to intact samples also to include possible effects of the structure of agricultural soils.

\section{Conclusion}

Suction controlled tests were carried out on a loamy soil prepared by compaction at different bulk densities and at different water contents. A sandy soil was also tested in order to study the effect of soil texture.

It was observed that the parameter $C_{\mathrm{s}}$ is independent of soil suction, in agreement with most of the results in the literature. Precompression stress was found to decrease as suction decreases, also in agreement with the results in the literature.

Suction can affect the shape of compression curves: for the loamy soil, the S-shape in case of low suctions was more apparent than that in the case of high suctions such as 180 and $200 \mathrm{kPa}$. This effect can be explained by the changes in soil aggregate stiffness occurring with the controlled suction.

An effect of soil texture and structure on the variation of the compression index with suction was observed: it was small and almost independent of the suction for the sandy soil whereas it was larger and varying when approaching the saturation state for the loamy soil.

From a practical point of view, the observation of constant compression index with respect to suction changes $(s>10 \mathrm{kPa})$ is quite useful for determining the intensity of soil compaction due to agricultural traffics. Firstly, to determine the compression index for 
different suction states, it is simply necessary to perform standard oedometer tests at constant water content instead of suction controlled oedometer tests; secondly, for soil compaction calculation, it is sufficient to include the suction effect in the precompression stress function, without considering any change in the compression index.

\section{Acknowledgements}

We are grateful to Mr. F. Bornet (UR1158, INRA, France) and Mr. E. Delaure (CERMES, ENPC, France) for their technical assistance. The authors thank the French GESSOL2 Program of the Ministry of the Environment and the ADD Program of the National Research Agency for providing their support to the DST project (Soil degradation due to compaction) of which this work is a part.

\section{References}

Adams, A. and Wulfsohn, D., 1998. Critical-state behaviour of an agricultural soil. Journal Agricultural Engineering Research, 70: 345-354.

AFNOR, 1997. Sols: reconnaissance et essais. Essai oedométrique. Partie 1: Essai de compressibilité sur matériaux fins quasi saturés avec chargement par paliers. XP P 94090-1, France.

Alexandrou, A. and Earl, R., 1998. The relationship among the pre-compaction stress, volumetric water content and initial bulk density of soil. Journal Agricultural Engineering Research, 71: 75-80.

Alonso, E.E., Gens, A. and Josa, A., 1990. A constitutive model for partially saturated soils. Géotechnique, 40: 405-430.

Arvidsson, J. and Keller, T., 2004. Soil precompression stress. I. A survey of Swedish arable soils. Soil Tillage Res., 77: 85-95.

Barden, L., McGown, A. and Collins, K., 1973. The collapse mechanism in partly saturated soil. Engieering Geology, 7: 49-60.

Bardet, J.P., 1997. Experimental Soil Mechanics. Prenctice-Hall, Inc., New Jersey.

Baumgartl, Th. and Köck, B., 2004. Modeling volume change and mechanical properties with hydraulic models. Soil Sci. Soc. Am. J., 68: 57-65.

Canarache, A., Horn, R. and Colibas, I., 2000. Compressibility of soils in a long term field experiment with intensive deep ripping in Romania. Soil Tillage Res., 56: 185-196.

Chen, Z.H., Fredlund, D.G. and Julian, K.M.G., 1999. Overall volume change, water volume change, and yield associated with an unsaturated compacted loess. Can. Geotech. J., 36 : 321-329.

Cui, Y.J., 1993. Etude du comportement d'un limon compacté non saturé et de sa modélisation dans un cadre élastoplastique. Ph.D. Thesis, Ecole Nationale des Ponts et Chaussées. Paris, France.

Cui, Y.J. and Delage, P., 1996. Yielding and plastic behaviour of an unsaturated compacted silt. Géotechnique, 46: 291-311.

Défossez, P., Richard, G., Boizard, H. and O'Sullivan, M., 2003. Modelling change in soil compaction due to traffic as function of soil water content. Geoderma, 116: 89-105.

Delage, P. and Cui, Y.J., 2000. L'eau dans les sols non saturés. Extrait de la collection, Techniques de l'ingénieur, C301: 1-20.

Delage, P., Howat, M. and Cui, Y.J., 1998. The relationship between suction and swelling properties in a heavily compacted unsaturated clay. Engineering Geology, 50: 31-48.

Fredlung, D.G., and Rahardjo, H., 1993. Soil mechanics for unsaturated soils. J. Wiley and Sons, Inc., New York.

Futai, M.M. and Almeida, M.S.S., 2005. An experimental investigation of the mechanical behaviour of an unsaturated gneiss residual soil. Géotechnique, 55: 201-213. 
Futai, M.M., Almeida, M.S.S., Conciani, W. and Filho, F., 2002. Experimental and theoretical evaluation of plate load test in collapsible soil. In: J.F.T. Jucá, T.M.P. de Campos and F.A.M. Marinho (Editors), Unsaturated Soils, Proc. of $3^{\text {rd }}$ Int. Conf. on Unsaturated Soils. Recife, Brasil, pp. 721-726.

Graham, J. and Li, C.C., 1985. Comparison of natural and remoulded plastic clay. J. Geotech. Engng. Div., ASCE, 111: 865-881.

Gregory, A.S., Whalley, W.R., Watts, C.W., Bird N.R.A., Hallett, P.D. and Whitmore, A.P., 2006. Calculation of the compression index and precompression stress from soil compression test data. Soil Tillage Res., 89: 45-57.

Gupta, S.C. and Larson, W.E., 1982. Modeling soil mechanical behaviour during tillage. In: P. Unger (Editor), Symposium on Predicting Tillage Effects on Soil Physical Properties and Processes. ASA Spec. Publ., Madison, WI, pp. 151-178.

Imhoff, S., Da Saliva, A.P. and Fallow, D., 2004. Susceptibility to compaction, load support capacity and soil compressibility of Hapludox. Soil Sci. Soc. Am. J., 68: 17-24.

Janbu, N., 1985. Soil models in offshore engineering. Géotechnique, 35: 241-281.

Jennings, J.E.B. and Burland, J.B., 1962. Limitations to the use of effective stresses concept in partly saturated soils. Géotechnique, 12: 125-144.

Keller, T., Arvidsson, J., Dawidowski, J.B. and Koolen, A.J., 2004. Soil compression stress. II. A comparison of different compaction tests and stress-displacement behaviour of the soil during wheeling. Soil Tillage Res., 77: 97-108.

Kogho, Y., Asano, I. and Tagashira, H., 2001. Modelling of state surfaces of unsaturated soils. In: K. Adachi and M. Fukue (Editors), Clay Science for engineering. Balkema, Rotterdam, pp. 467-474.

Larson, W.E., Gupta, S.C. and Useche, R.A., 1980. Compression of agricultural soils from eight soil orders. Soil Sci. Soc. Am. J., 44: 450-457.

Lebert, M. and Horn, R., 1991. A method to predict the mechanical strength of agricultural soils. Soil Tillage Res., 19: 275-286.

Leroueil, S., 1996. Compressibility of clays: fundamental and practical aspects. J. Geotech. Engng. Div., ASCE 122: 534-543.

Mancuso, C., Vassallo, R. and d'Onofrio, A., 2002. Small strain behavior of a silty sand in controlled-suction resonant column-torsional shear tests. Can. Geotech. J., 39: 22-31.

McBride, R.A., 1989. Estimation of density-moisture-stress functions from uniaxial compression of unsaturated, structured soils. Soil Tillage Res., 13: 383-397.

Mosaddeghi, M.R., Hemmat, A., Hajabbasi, M.A., Vafaeian, M. and Alexandrou, A., 2006. Plate sinkage versus confined compression tests fir In Situ soil compressibility studies. Biosystems Engineering, 93: 325-334.

O'Sullivan, M.F., 1992. Uniaxial compaction effects on soil physical properties in relation to soil type and cultivation. Soil Tillage Res., 24: 257-269.

Perret, D., Locat, J. and Leroueil, S., 1995. Strength development with burial in fine-grained sediments from the Saguenay Fjord, Quebec. Can. Geotech. J., 32: 247-262.

Rampino, C., Mancuso, C. and Vinale, F., 2000. Experimental behaviour and modelling of an unsaturated compacted soil. Can. Geotech. J., 37: 748-763.

Romero, E., Gens, A. and Lloret, A., 2003. Suction effects on a compacted clay under nonisothermal conditions. Géotechnique, 53: 65-81.

Rücknagel, J., Hofmann, B., Paul, R., Christen, O. and Hülsbergen, K.J., 2007. Estimating precompression stress of structured soils on the basis of aggregate density and dry bulk density. Soil Tillage Res., 92: 213-220.

Salire, E.V., Hammel, J.E. and Hardcastle, J.H., 1994. Compression of intact subsoils under short-duration loading. Soil Tillage Res., 31: 235-248. 
Smith, P.R., Jardine, R.J. and Hight, D.W., 1992. On the yielding of Bothkennar clay. Géotechnique, 42: 257-274.

Smith, C.W., Johnston, M.A. and Lorentz, S., 1997. Assessing the compaction susceptibility of South African forestry soils. II, Soil properties affecting compactibility and compressibility. Soil Tillage Res., 43: 335-354.

Smith, G.N. and Smith, Ian G.N., 1998. Elements of Soil Mechanics (7 ${ }^{\text {th }}$ ed.). Blackwell Science, Cambridge.

Wang, Q., Pufahl, D.E. and Fredlund, D.G., 2002. A study of critical state on an unsaturated silty soil. Can. Geotech. J., 39: 213-218.

Zhang, H., Hartge, K.H. and Ringe, H., 1997. Effectiveness of organic matter incorporation in reducing soil compactibility. Soil Sci. Soc. Am. J., 61: 239-245. 


\section{Tables}

Table 1 Variations in the compression index with suction reported in literature for compression tests with controlled suction

\begin{tabular}{|c|c|c|c|c|c|c|c|}
\hline Reference & Soil & Sample structure & Controlled suctions & $\begin{array}{l}\text { Mechanical tests/ technique used } \\
\text { for suction controlling }\end{array}$ & $\begin{array}{l}\text { Number } \\
\text { of } \\
\text { replicates } \\
\text { per test }\end{array}$ & $\begin{array}{l}\text { Dry bulk } \\
\text { density } \\
\mathrm{Mg} \mathrm{m}^{-3}\end{array}$ & $\begin{array}{l}\text { Variation of } \\
\text { compressibility } \\
\text { as soil suction increases } \mathrm{s}^{\mathrm{a}}\end{array}$ \\
\hline Cui (1993) & Clay loam & $\begin{array}{l}\text { Remoulded samples } \\
\text { sieved }<0.4 \mathrm{~mm}\end{array}$ & $\begin{array}{l}4 \text { suctions } \\
s=[200-1500 \mathrm{kPa}]\end{array}$ & Triaxial / osmotic technique & 1 & 1.67 & $\begin{array}{l}\text { Decrease } \\
C_{\mathrm{c}}=[0.315-0.161]\end{array}$ \\
\hline $\begin{array}{l}\text { Adams and } \\
\text { Wulfsohn } \\
\text { (1998) }\end{array}$ & $\begin{array}{l}\text { Sandy clay } \\
\text { loam }\end{array}$ & $\begin{array}{l}\text { Remoulded samples } \\
\text { sieved }<2 \mathrm{~mm}\end{array}$ & $\begin{array}{l}2 \text { suctions } \\
s=[0,50 \mathrm{kPa}]\end{array}$ & Triaxial / axis translation & 1 & 1.2 & $\begin{array}{l}\text { Increase } \\
C_{\mathrm{c}}=[0.207,0.575]\end{array}$ \\
\hline $\begin{array}{l}\text { Chen et al } \\
\text { (1999) }\end{array}$ & Loam & Remoulded samples & $\begin{array}{l}4 \text { suctions } \\
s=[0-200 \mathrm{kPa}]\end{array}$ & Triaxial / axis translation & 1 & 1.70 & $\begin{array}{l}\text { Decrease } \\
C_{\mathrm{c}}=[0.253-0.138]\end{array}$ \\
\hline $\begin{array}{l}\text { Sivakumar } \\
\text { and Doran } \\
\text { (2000) }\end{array}$ & Clay & $\begin{array}{l}\text { Remoulded samples } \\
\text { sieved }<1.12 \mathrm{~mm}\end{array}$ & $\begin{array}{l}4 \text { suctions } \\
s=[0-400 \mathrm{kPa}]\end{array}$ & Triaxial / axis translation & 1 & 1.98 & $\begin{array}{l}\text { Increase and decrease } \\
C_{\mathrm{c}}=[0.276-0.207]\end{array}$ \\
\hline $\begin{array}{l}\text { Rampino et } \\
\text { al (2000) }\end{array}$ & Sandy loam & Intact samples & $\begin{array}{l}4 \text { suctions } \\
s=[0-300 \mathrm{kPa}]\end{array}$ & Oedometer / axis translation & 1 & 1.97 & $\begin{array}{l}\text { Decrease } \\
C_{\mathrm{c}}=[0.051-0.035]\end{array}$ \\
\hline $\begin{array}{l}\text { Wang et al } \\
(2002)\end{array}$ & Clay loam & $\begin{array}{l}\text { Remoulded samples } \\
\text { sieved }<0.75 \mathrm{~mm}\end{array}$ & $\begin{array}{l}3 \text { suctions } \\
s=[0-300 \mathrm{kPa}]\end{array}$ & Triaxial / axis translation & 1 & 1.90 & $\begin{array}{l}\text { Constant } \\
C_{\mathrm{c}}=0.138\end{array}$ \\
\hline \multirow[t]{2}{*}{$\begin{array}{l}\text { Mancuso et } \\
\text { al (2003) }\end{array}$} & Sandy loam & $\begin{array}{l}\text { Remoulded samples } \\
\text { sieved }<0.4 \mathrm{~mm}\end{array}$ & $\begin{array}{l}4 \text { suctions } \\
s=[0-300 \mathrm{kPa}]\end{array}$ & Triaxial / axis translation & 1 & 1.77 & $\begin{array}{l}\text { Decrease } \\
C_{\mathrm{c}}=[0.092-0.069]\end{array}$ \\
\hline & & & & & & 1.93 & $\begin{array}{l}\text { Decrease } \\
C_{\mathrm{c}}=[0.051-0.35]\end{array}$ \\
\hline \multirow[t]{2}{*}{$\begin{array}{l}\text { Romero et } \\
\text { al (2003) }\end{array}$} & Clay & Remoulded samples & $\begin{array}{l}3 \text { suctions } \\
s=[10-450 \mathrm{kPa}]\end{array}$ & Oedometer / axis translation & 1 to 3 & 1.37 & $\begin{array}{l}\text { Decrease } \\
C_{\mathrm{c}}=[0.270-0.230]\end{array}$ \\
\hline & & & & & & 1.67 & $\begin{array}{l}\text { Decrease } \\
C_{\mathrm{c}}=[0.143-0.106]\end{array}$ \\
\hline \multirow{2}{*}{$\begin{array}{l}\text { Futai and } \\
\text { Almeida } \\
\text { (2005) }\end{array}$} & $\begin{array}{l}\text { Sandy clay } \\
\text { Silt loam }\end{array}$ & Intact & $\begin{array}{l}4 \text { suctions } \\
s=[0-500 \mathrm{kPa}]\end{array}$ & Triaxial / axis translation & 1 & 1.5 & $\begin{array}{l}\text { Increase } \\
C_{\mathrm{c}}=[0.460-0.759]\end{array}$ \\
\hline & & & & & & 1.9 & $\begin{array}{l}\text { Increase } \\
C_{\mathrm{c}}=[0.322-0.414]\end{array}$ \\
\hline
\end{tabular}

$\bar{a}$ the compression index was estimated from the compressibility $\lambda$ using the relation $C_{\mathrm{c}}=2.3 \lambda$ 


\section{Figure captions}

Fig. 1: Osmotic oedometer.

Fig. 2: Water retention curve of compacted loamy soil at $1.1 \mathrm{Mg} \mathrm{m}^{-3}$ dry bulk density measured using a high capacity tensiometer.

Fig. 3: Variation of water volume in the capillary tube: (a) as a function of time before the equilibrium state of a value of suction controlled at $50 \mathrm{kPa}$ for a sample initially prepared at a suction of $200 \mathrm{kPa}$; (b) under the step-loading vertical stress during compression test under a controlled suction of $50 \mathrm{kPa}$ (first test series with an initial dry bulk density of $1.1 \mathrm{Mg} \mathrm{m}^{-3}$ ).

Fig. 4: Typical change in void ratio $(e)$ as a function of vertical stress $\left(\sigma_{v}\right)$ with the compression index $\left(C_{\mathrm{c}}\right)$, the parameter $\left(C_{\mathrm{s}}\right)$ and the precompression stress $\left(p_{\mathrm{c}}\right)$.

Fig. 5: Compression curves of the loamy soil for various controlled suctions: $200 \mathrm{kPa}$ (black square), $180 \mathrm{kPa}$ (black triangle), $100 \mathrm{kPa}$ (grey triangle), $50 \mathrm{kPa}$ (black circle), $10 \mathrm{kPa}$ (grey square), $0 \mathrm{kPa}$ (grey circle) (first test series with an initial dry bulk density of $1.1 \mathrm{Mg} \mathrm{m}^{-3}$ ).

Fig. 6: $\Delta e / \Delta \log \sigma \mathrm{v}$ as a function of vertical stress for different controlled suctions: $200 \mathrm{kPa}$ (black square), $180 \mathrm{kPa}$ (black triangle), $100 \mathrm{kPa}$ (grey triangle), $50 \mathrm{kPa}$ (black circle), $10 \mathrm{kPa}$ (grey square), $0 \mathrm{kPa}$ (grey circle) (same soil conditions as Fig. 5).

Fig. 7: Variation of the compression index (square) as a function of suction in comparison to the average of $\Delta e / \Delta \log \sigma \mathrm{v}$ (triangle). Both were determined from $\Delta e / \Delta \log \sigma_{\mathrm{v}}$ curve (first test series with an initial dry bulk density of $1.1 \mathrm{Mg} \mathrm{m}^{-3}$ ).

Fig. 8: (a) Compression curves of the loamy soil for various controlled suctions (b) $\Delta e / \Delta \log \sigma_{\mathrm{v}}$ as a function of vertical stress for various suctions controlled: $200 \mathrm{kPa}$ (black square), $80 \mathrm{kPa}$ (black triangle), $20 \mathrm{kPa}$ (grey square), $0 \mathrm{kPa}$ (grey circle) (third test series with an initial dry bulk density of $1.45 \mathrm{Mg} \mathrm{m}^{-3}$ ).

Fig. 9: (a) Compression curves of the sandy soil for various controlled suctions (b) $\Delta e / \Delta \log \sigma_{\mathrm{v}}$ as a function of vertical stress for various suctions controlled: $200 \mathrm{kPa}$ (black square), $80 \mathrm{kPa}$ (black triangle), $0 \mathrm{kPa}$ (grey circle) (fourth test series with an initial dry bulk density of $\left.1.45 \mathrm{Mg} \mathrm{m}^{-3}\right)$.

Fig. 10: Variation of the compression index $\left(C_{\mathrm{c}}\right)$ as a function of controlled suction for both procedures for soil samples preparation: samples from pre-compaction of soil at an initial water content of $0.125 \mathrm{~g} \mathrm{~g}^{-1}$ (square) and samples from pre-compaction of soils at different initial suctions (triangle). Loamy soil with an initial dry bulk density of $1.1 \mathrm{Mg} \mathrm{m}^{-3}$.

Fig. 11: Variation of the compression index $\left(C_{\mathrm{c}}\right)$ as a function of controlled suction for the samples with an initial water content of $0.125 \mathrm{~g} \mathrm{~g}^{-1}$ for the loamy soil with dry bulk density of $1.1 \mathrm{Mg} \mathrm{m}^{-3}$ (black square) or $1.45 \mathrm{Mg} \mathrm{m}^{-3}$ (empty square), for the sandy soil (triangle) with dry bulk density of $1.45 \mathrm{Mg} \mathrm{m}^{-3}$. 


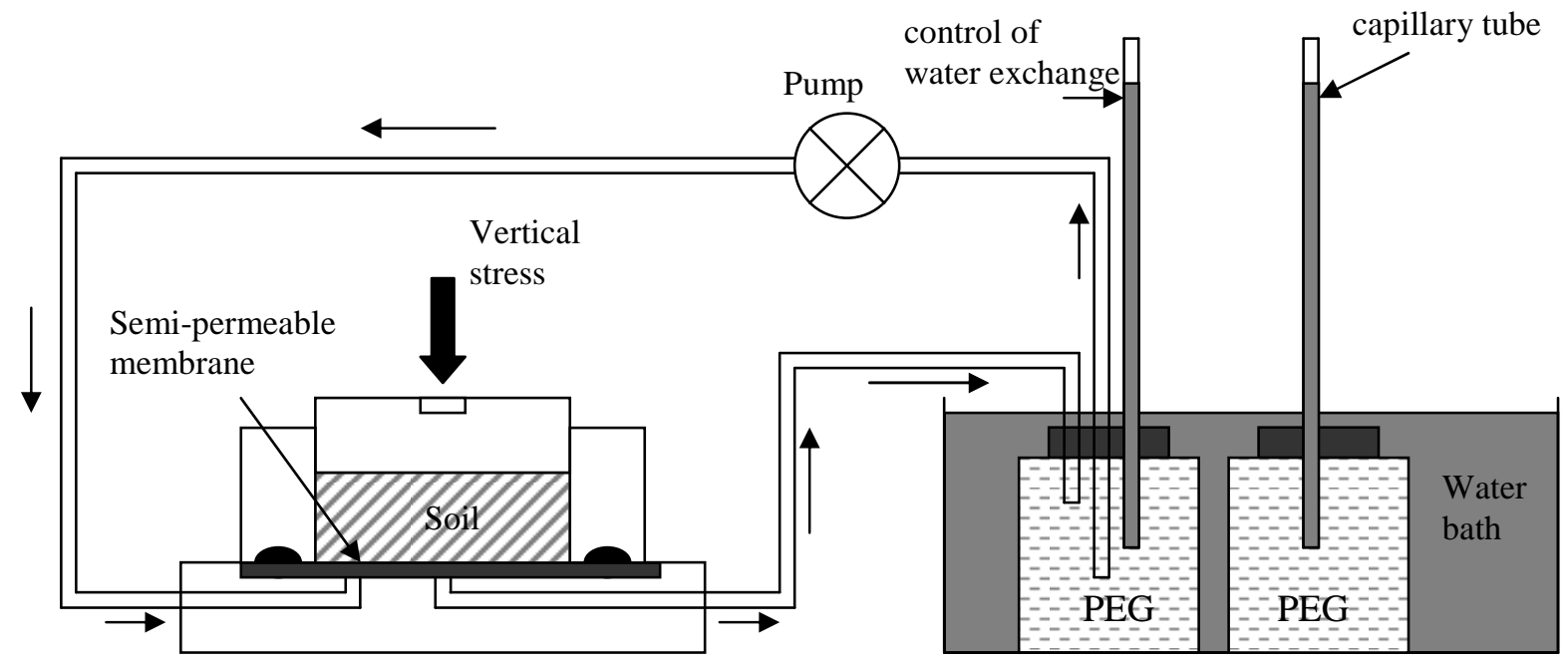

Fig. 1 


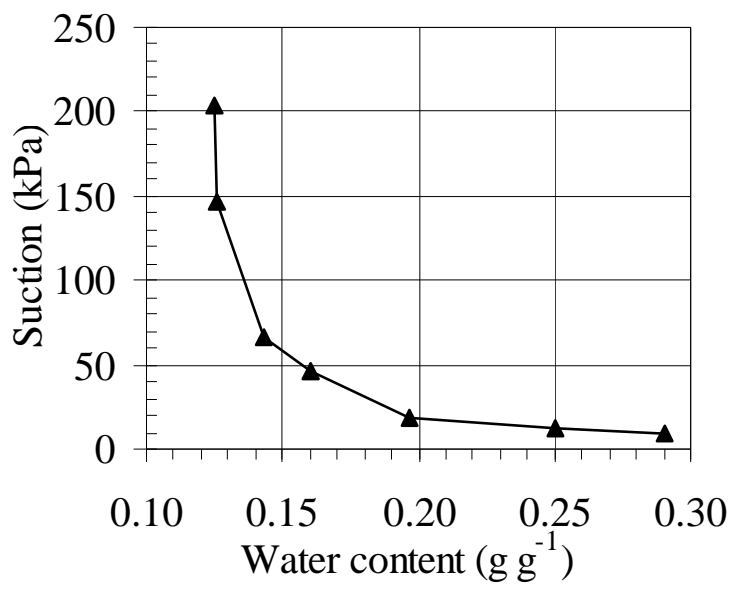

Fig. 2 
(a)

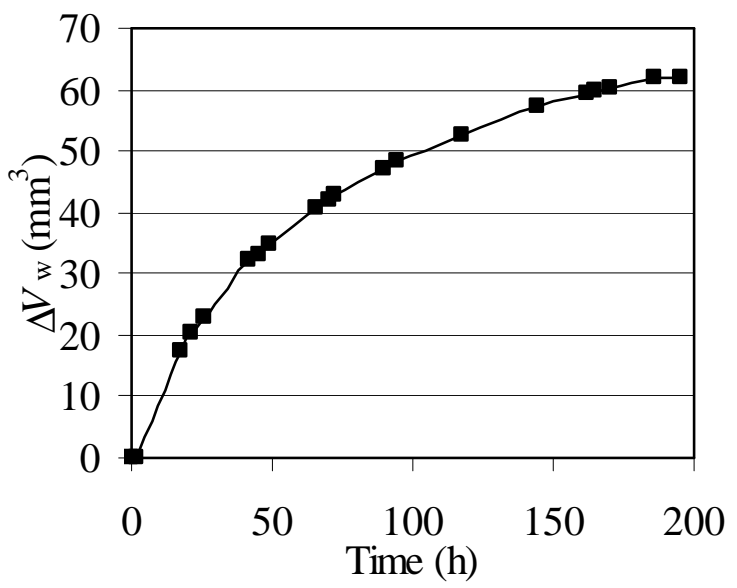

(b)

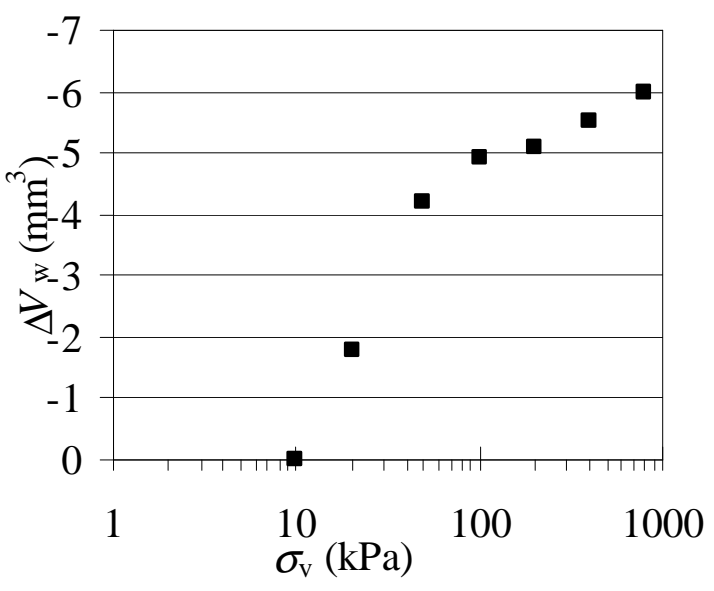

Fig. 3 


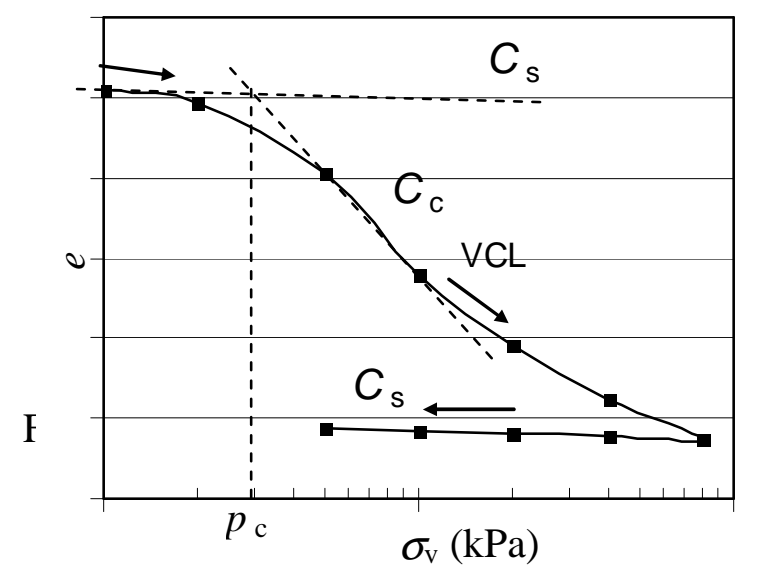




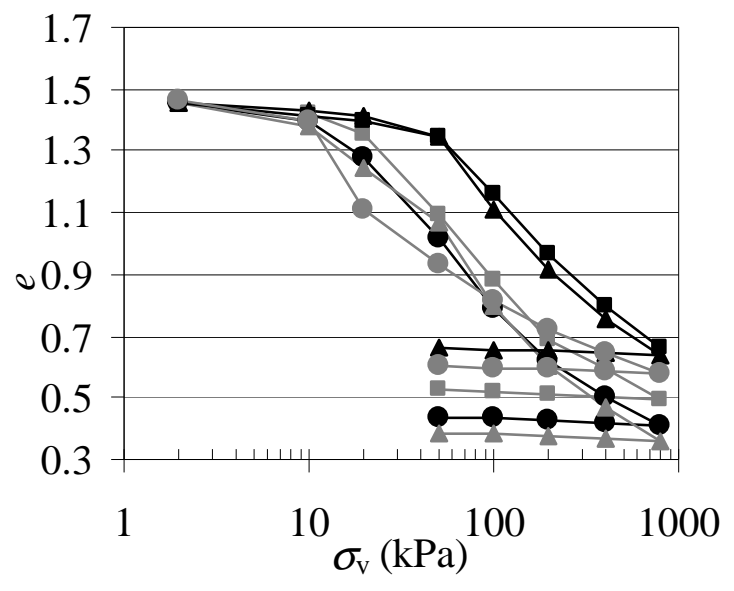

Fig. 5 


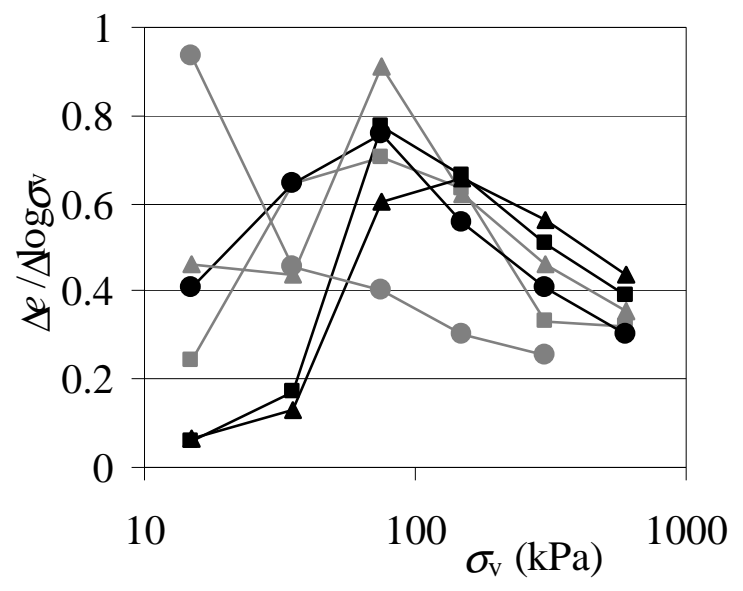

Fig. 6 


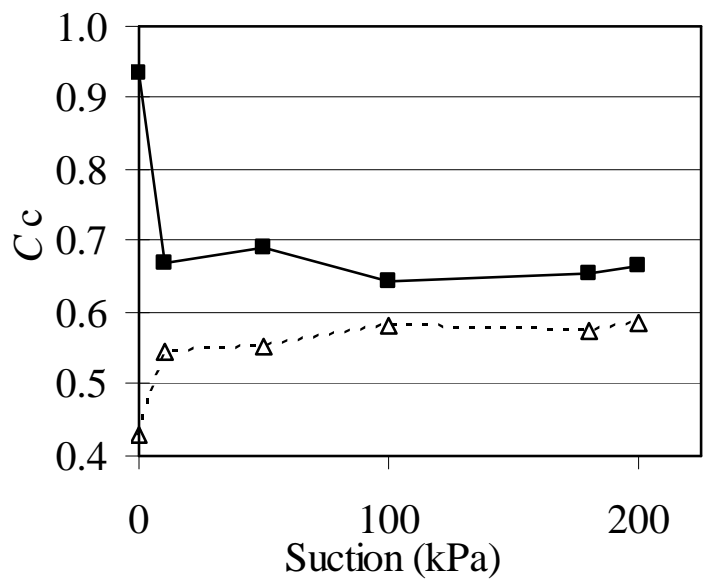

Fig. 7 
(a)

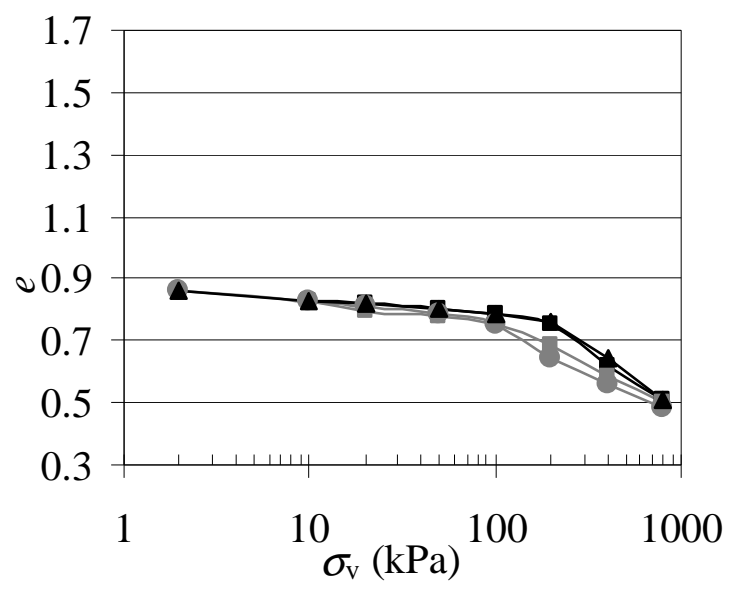

(b)

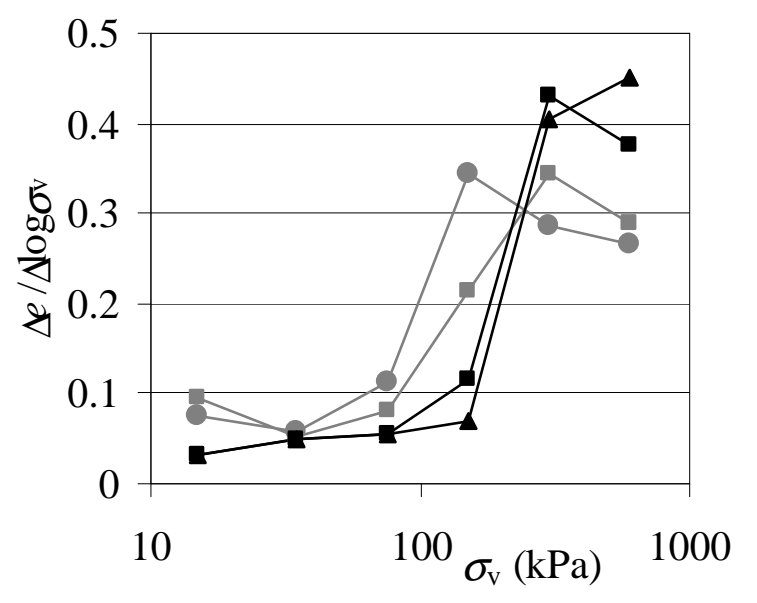

Fig. 8 
(a)

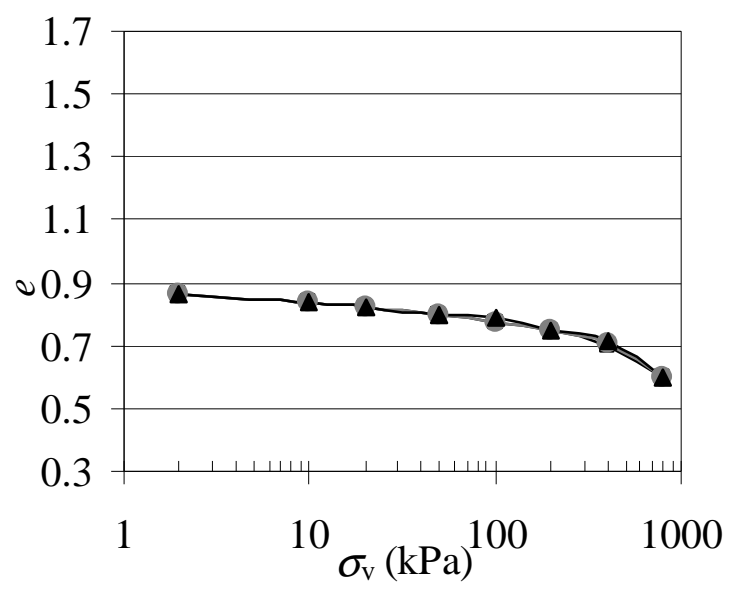

(b)

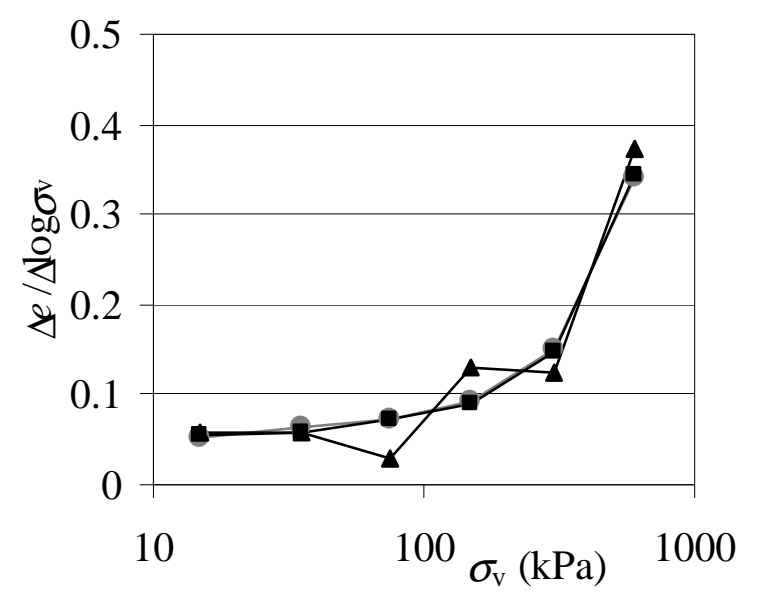

Fig. 9 


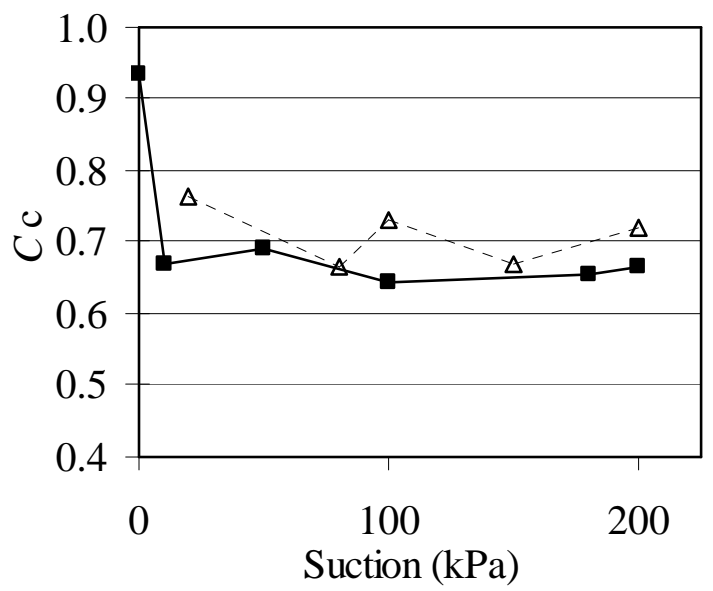

Fig. 10 


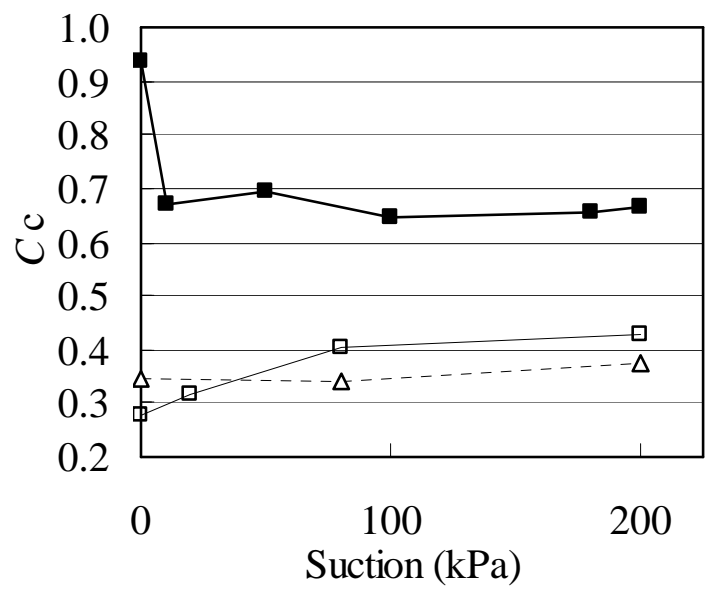

Fig. 11 